\title{
ANALISA PENGARUH KUALITAS HUBUNGAN DAN LOYALITAS PELANGGAN DENGAN ETIKA PERILAKU PENJUALAN DI INDUSTRY KEUANGAN DI PEKANBARU (STUDI KASUS PADA SECTOR LEASING/PEMBIAYAAN MOBIL)
}

\author{
RIKI HANRI MALAU \\ Fakultas Ekonomi dan Ilmu Sosial UIN Sultan Syarif Kasim Riau
}

\begin{abstract}
Abstrak
Today the awareness of the ethical behavior getting higher in competitive pressures, the implications of ethical conduct for leasing institutions have become an important determinant of customer loyalty. The aim of this study was to develop a conceptual framework to investigate the relationship between sales of ethical behavior, relationship quality and customer loyalty. The proposed model is tested on data collected from 70 people salesman from various leasing in Pekanbaru. Structural equation modeling techniques are employed using SPSS V.17 to verify the reliability and validity of the scale and to test the effect of. Results showed that positive ethical behavior is influenced by the quality of relationships and costumer loyalty on sales operation. The findings also show that customer confidence in leasing has a positive effect on leasing customer commitment. Results of this study the position of customer trust and customer commitment as the main mechanism through which the beneficial effects of the ethical behavior of sales is realized. However, research shows that the perception of ethical behavior has a huge impact on the development and maintenance of customer relationships with leasing institutions. For the leasing manager, who appreciate the importance of long-term relationships with their customers, should minimize unethical sales behavior to reaches the environment of intense competition
\end{abstract}

\section{PENDAHULUAN}

Industri pembiayaan di Indonesia sesungguhnya belumlah terlalu lama, terutama bila dibandingkan dengan di negara-negara maju. Menurut Assosiasi Perusahaan Pembiayaan Indonesia (APPI) industri ini mulai tumbuh di Indonesia pada 1974 (Turisman, 2014). Perusahaan pada sektor pembiayaan ini memerlukan dana relatif besar dengan biaya tetap yang tinggi dan penjualan relatif stabil hal ini dikarenakan transportasi menjadi suatu kebutuhan yang cukup penting karena dapat memudahkan pendistribusian barang dan jasa antar wilayah dan juga mempermudah masyarakat dalam melakukan aktivitas sehari-hari. Hal ini mengindikasikan multifinance kian dikenal pelaku usaha nasional. 
Ada beberapa hal menarik jika kita mencermati konsentrasi dan perkembangan perusahaan leasing. Pada era tahun 1989 industri ini di Indonesia cenderung berupaya memperbesar asset, perburuan asset tersebut diantaranya disebabkan tantangan perekonomian menuntut mereka tampil lebih besar, sehat dan kuat. Perusahaan yang tidak beranjak dari skala semula tampak kesulitan dana dan akhirnya tutup sama sekali. Dukungan asset dan skala usaha yang besar, muncul anggapan perusahaan lebih handal dibandingkan yang lain. Bagi yang kapasitasnya memang terbatas, mereka berupaya agar tetap konsisten dan eksis dalam industri perusahaan pembiayaan. Dimulailah saling penjajakan di antara sesama perusahaan sektor pembiayaan. Skenario selanjutnya, banyak perusahaan leasing yang melakukan penggabungan (merger/akuisisi) menjadi satu grup. Tampaknya langkah ini membuahkan hasil positif, selain modal dan asset bertambah, kredibilitas dan penguasaan pasar pun ikut mengalami peningkatan (Turisman, 2014).

Perkembangan industry leasing ini ditandai dengan penguasaan permodalan yang semakin besar. Bank Indonesia menjelaskan dalam majalah SWA hampir membukukan total penyaluran pembiayaan selama 2013 sebesar Rp 340,7 triliun, tumbuh 14,98 persen dibandingkan tahun 2012 yang sebesar Rp $296.3 \quad$ triliun.

Tabel I.1 : Tabel perkembangan asset dan pembiayaan dari sector leasing di Indonesia Tahun 2009 - 2013

\begin{tabular}{|c|c|c|c|c|c|}
\hline NO & Keterangan & $\begin{array}{c}\text { Asset } \\
\text { (triliun) }\end{array}$ & $\begin{array}{c}\text { Pertumbuuhan } \\
(\%)\end{array}$ & $\begin{array}{c}\text { Pembiayaan } \\
\text { (triliun) }\end{array}$ & $\begin{array}{c}\text { Pertumbuuh } \\
\text { an (\%) }\end{array}$ \\
\hline 1 & 2009 & 265.4 & - & 198.6 & - \\
\hline 2 & 2010 & 298.8 & 11,17 & 224.6 & 11,57 \\
\hline 3 & 2011 & 328.6 & 9,06 & 273.8 & 21,90 \\
\hline 4 & 2012 & 331.8 & 0.97 & 296.3 & 8.21 \\
\hline 5 & 2013 & 387.2 & 16,72 & 340.7 & 14,98 \\
\hline
\end{tabular}

Sumber : Majalah SWA

Dari tabel diatas dapat terlihat jumlah perkembangan pembiayaan dan asset dari leasing menunjukkan perkembangan yang sangat menggembirakan dari setiap tahunnya. Untuk asset selama lima tahun terjadi perkembangan sebesar 45.89 persen sedangkan untuk pembiayaan terjadi perkembangan sebesar 71.55 persen. Perkembangan ini dimungkinkan oleh karena iklim ekonomi yang semakin membaik di Indonesia. Selain itu kemampuan tenaga penjual dalam melakukan penjualan juga merupakan salah satu yang mempengaruhi peningkatan pembiayaan ini.

Namun demikian Pertumbuhan jumlah perusahaan multifinance mengalami kemerosotan sejak 2007, akibat sejumlah perusahaan pembiayaan terpaksa dibekukan karena gagal memenuhi kewajiban, seperti memenuhi persyaratan modal minimal dan 
memberikan laporan keuangan. Selain diakibatkan oleh pembekuan sejumlah perusahaan, menurunnya jumlah perusahaan multifinance juga diakibatkan karena proses merger, beralih unit usaha, maupun bangkrut. Selain itu, juga disebabkan karena terbatasnya dana perusahaan pembiayaan skala kecil, sehingga berpengaruh pada bank yang ingin menyalurkan kreditnya. Perusahaan kecil mengalami kesulitan beroperasi karena kompetisi binis multifinance yang ketat.

Dengan tujuan meningkatkan produktivitas tidak sedikit perusahaan pembiayaan mobil menggunakan jumlah tenaga pemasar yang banyak. Dengan jumlah tenaga pemasar yang banyak mereka berharap bisa mendapatkan lebih banyak konsumen dari pada perusahaan yang hanya memiliki sedikit tenaga penjual kredit. Secara sederhana dapat dilihat bahwa semakin banyak tenaga penjual kredit yang mereka miliki berarti mereka dapat menjangkau pasar lebih luas. Informasi mengenai produk pembiayaan mereka dapat disampaikan ke lebih banyak calon konsumen. Namun jumlah tenaga pemasar yang banyak kemudian bisa tidak menimbulkan efek yang diharapkan apabila kinerja atau performa dari tenaga pemasar tersebut tidak maksimal atau mereka tidak bisa mencapai target yang diberikan.

Keberhasilan perusahaan dalam mempertahankan hasil penjualan tidak lepas dari peran para tenaga penjualan. Dengan peran tenaga penjualan, maka perusahaan akan mampu menjalin hubungan yang lebih dekat dan lebih baik dengan konsumen. Semakin dekat dan baiknya hubungan antara perusahaan dengan para konsumen akan mempermudah perusahaan dalam meningkatkan keberhasilan pemasaran.

Tenaga penjual sebagai frontman yang berhadapan dengan pelanggan mempunyai pengaruh dalam meningkatkan citra perusahaan. Untuk itu tenaga penjual harus mempunyai bekal etika yang etis dalam menjaga kualitas hubungan sehingga pelanggan akan terlayani dengan baik dan pada akhirnya akan meningkatkan loyalitas pelanggan.

Kesadaran etika bagi tenaga penjual didalam tekanan persaingan yang kuat membawa implikasi didunia pemasaran, sehingga menjadi faktor penentu yang penting dalam mbentuk konsumen yang loyal. Oleh karena itu, sebagian besar pemasar menyadari bahwa saat ini penting untuk memulai mempertahankan hubungan dengan pelanggan dalam jangka waktu yang panjang (Liu et al, 2008.) Untuk itu lembaga keuangan perlu memaksimalkan kinerja jangka panjang dalam berbagai aspek pemasaran seperti retensi dan loyalitas pelanggan, yang harus dibangun, dipelihara dan ditingkatkan sebagai hubungan jangka panjang yang saling menguntungkan terhadap pelanggan (Alrubaiee \& Alnazer, 2010). Implikasinya adalah semakin pentingnya faktor non-harga, seperti etika penjualan sebagai suatu perilaku bagi tenaga penjualan dalam membentuk diferensiasi perusahaan, serta mencapai pertumbuhan pendapatan yang lebih tinggi dan pangsa pasar yang lebih baik. Fokus dalam membangun hubungan yang sukses dengan pelanggan 
adalah dengan menempatkan tenaga penjualan dalam sebagai posisi yang strategis dalam berhadapan dengan pelanggan. Selain itu, etika perilaku penjualan dapat memainkan peran penting dalam pembentukan dan pemeliharaan hubungan jangka panjang dengan pelanggan. Namun, dalam konteks jasa keuangan, kemampuan tenaga penjual untuk mempengaruhi loyalitas pelanggan dan ketergantungan pada lembaga keuangan dapat ditentukan oleh perilaku yang diterapkan tenaga penjual pada saat berinteraksi dengan pelanggan.

Berdasarkan permasalahan diatas diatas maka penulis tertarik untuk melakukan penelitian dengan judul :

analisa pengaruh kualitas hubungan dan loyalitas pelanggan dengan etika perilaku penjualan di industry keuangan di pekanbaru (studi kasus pada sector leasing/pembiayaan mobil).

\section{HASIL DAN PEMBAHASAN Loyalitas Pelanggan}

Mempunyai sikap loyalitas yang tinggi sehingga efektivitas dan efisiensi pencapaian tujuan perusahaan akan tercapai Pengertian loyalitas berasal dari bahasa inggris 'loyal' yang artinya setia. dan kesetiaan adalah kualitas yang menyebabkan kita tidak menggemingkan dukungan dan pembelaan kita pada sesuatu. Loyalitas lebih banyak bersifat emosional, loyalitas adalah kualitas perasaan, dan perasaan tak selalu membutuhkan penjelasan rasional.

Customer loyalty atau loyalitas pelanggan merupakan ukuran kesetiaan seorang pelanggan pada sebuah merek. secara harfiah loyal berati setia, atau loyalitas dapat diartikan sebagai suatu kesetiaan. kesetiaan ini timbul tanpa adanya paksaan, tetapi timbul dari kesadaran sendiri pada masa lalu. usaha yang dilakukan untuk menciptakan kepuasan lebih cendrung mempengaruhi sikap konsumen. sedangkan konsep loyalitas konsumen lebih menekankan kepada prilaku pembeliannya. (Hasan, 2008)

Sedangkan Kotler (2004) menjelaskan Loyalitas atau kesetiaan sebagai komitmen yang dipegang kuat untuk membeli atau berlangganan lagi produk atau jasa tertentu di masa depan meskipun ada pengaruh situasi dan usaha pemasaran yang berpotensi menyebabkan perubahan perilaku.

Pengertian tentang seorang pelanggan yang loyal adalah pelanggan yang memiliki ciri-ciri antara lain melakukan pembelian secara berulangulang pada badan usaha yang sama secara teratur, membeli lini produk dan jasa yang ditawarkan oleh badan usaha yang sama, memberitahukan kepada orang lain tentang kepuasan-kepuasan yang didapat dari badan usaha, dan menunjukkan kekebalan terhadap tawaran-tawaran dari badan usaha pesaing. Loyalitas konsumen secara umum dapat diartikan sebagai kesetiaan seseorang atas suatu produk, baik barang maupun jasa tertentu. (Griffin, 2009)

Terciptanya kepuasan dapat memberikan beberapa manfaat diantaranya hubungan antara perusahaan dan pelanggan menjadi harmonis, menjadi dasar bagi pembelian ulang dan menciptakan loyalitas pelanggan serta rekomendasi dari mulut ke mulut yang menguntungkan perusahaan. 
Ada beberapa keuntungan yang diperoleh perusahaan apabila mempunyai pelanggan yang loyal (Griffin 2009) :

1. Mengurangi biaya pemasaran

2. Mengurangi biaya transaksi

3. Mengurangi biaya turn over pelanggan

4. Meningkatkan penjualan silang yang akan memperbesar pangsa pasar perusahaan.

5. Word of mouth yang lebih positif dengan asumsi bahwa pelanggan yang loyal juga berarti mereka yang merasa puas

6. Mengurangi biaya kegagalan (seperti biaya pergantian, dll).

Loyalitas konsumen berarti konsumen berkomitmen untuk terus berbelanja disuatu ritel tertentu dan tidak berlangganan pada ritel lain. Selain tu loyalitas konsumen juga merupakan suatu bentuk prilaku pembelian ulang sebagai Loyalitas konsumen berarti konsumen berkomitmen untuk terus berbelanja hasil keputusan yang diambil konsumen secara sadar untuk terus membeli brand yang sama. Konsumen yang memiliki kepuasan tingkat tinggi akan cenderung untuk melakukan pembelian kembali dimasa yang akan datang dan merekomendasikan sumber kepuasan tersebut kepada orang lain. (Carpenter dan Fairhurt, 2005).

Ciri-ciri Pelanggan yang Loyal (Griffin, 2009)

a. Melakukan pembelian ulang secara teratur.

b. Melakukan pembelian lini produk yang lainnya.

c. Memberikan referensi pada orang lain. d. Menunjukkan kekebalan terhadap tarikan dari pesaing/ tidak mudah terpengaruh oleh bujukan pesaing)

Untuk dapat menjadi pelanggan yang loyal, seorang pelanggan harus memulai beberapa tahapan. Proses ini berlangsung lama dengan penekanan dan perhatian yang berbeda untuk masingmasing tahap karena setiap tahap mempunyai kebutuhan yang berbeda. Dengan memperhatikan masing-masing tahapan dan memenuhi kebutuhan dalam setiap tahap tersebut, perusahaan memiliki peluang yang lebih besar untuk membentuk calon pembeli menjadi pelanggan loyal dan klien perusahaan. Hill (2006) menjelaskan bahwa tingkatan loyal terbagi atas 6 tingkat, yaitu :

Suspect Bagian ini termasuk semua pembeli produk atau jasa dalam pemasaran, jadi suspects adalah menyadari akan produk atau jasa perusahaan atau tidak mempunyai kecenderungan terhadap pembelian.

a. Prospects adalah pelanggan potensial yang mempunyai daya tarik terhadap perusahaan tetapi belum mengambil langkah untuk melakukan bisnis dengan perusahaan.

b. Customers adalah suatu tipe pembelian produk (walaupun dalam kategori ini termasuk beberapa pembelian ulang) yang tidak memiliki loyalitas pada perusahaan.

c. Clients adalah Pembelian ulang yang menunjukkan loyalitas pada perusahaan tetapi lebih memiliki dorongan pasif daripada aktif terhadap perusahaan.

d. Advocates adalah client yang memberikan dorongan yang positif 
pada perusahaan dengan merekomendasikannya kepada orang lain.

e. Partners adalah hubungan yang sangat erat antara konsumen dengan supplier yang keduanya saling memperlihatkan keuntungan.

\section{Manajemen Hubungan Pelanggan}

Konsep manajemen hubungan pelanggan tidak lepas dari perspektif Relationship Marketing. Chaffey (2006), relationship marketing adalah aplikasi pengetahuan terkini mengenai para pelanggan individual secara konsisten untuk keperluan perancangan produk dan jasa yang dikomunikasikan secara interaktif dalam rangka mengembangkan hubungan jangka panjang berkesinambungan yang saling menguntungkan. Asumsi utama Customer Relationship Management bahwa sama dengan Relationship Marketing yaitu bahwa membangun relasi jangka panjang merupakan cara terbaik untuk menciptakan loyalitas pelanggan. Selain itu pelanggan yang loyal cenderung lebih profitable daripada pelanggan yang tidak loyal.

Dalam menjalin suatu hubungan dengan pelanggan, perusahaan harus mengetahui karakteristik tertentu yang dibutuhkan untuk membuktikan bahwa suatu hubungan itu eksis sehingga dapat memberikan sumbangan yang positif terhadap hubungan tersebut. Hollensen (2003) terdapat dimensi kunci dalam membangun sebuah hubungan, yaitu (1) ikatan, merupakan bagian dari suatu hubungan di mana kedua pihak membentuk suatu kesatuan untuk mencapai tujuan; (2) kepercayaan, yaitu suatu keyakinan di mana masing-masing pihak akan menepati janjinya dan tidak akan merugikan pihak lainnya; (3) empati, yaitu dimensi dan hubungan bisnis yang memungkinkan kedua pihak melihat situasi dari sudut pandang pihak lawannya yang dapat diartikan sebagai usaha memahami hasrat dan keinginan seseorang; (4) resiprokal, yaitu di mana kedua pihak saling memberikan sesuatu yang menguntungkan keduanya.

Proses yang dihadapi pelanggan harus melahirkan suatu kenyamanan, dan kesan yang tak terlupakan sehingga akan membentuk suatu proses Alami pelanggan. Dengan adanya hubungan ini, maka pelanggan akan memperoleh manfaat, yang dibagi lagi menjadi tiga manfaat, yaitu : pelanggan senang membeli pada orang yang dikenalnya, karena merasa resikonya berkurang atau disebut dengan Confidence Benefit. Kedua adalah Social Benefit, yaitu setelah memiliki Relationship, maka pelanggan tidak akan merasa asing terhadap suatu tempat meskipun banyak orang, dan yang ketiga adalah Special Treatment Benefit, karena dianggap sebagai Customer yang loyal maka pelanggan tersebut memperoleh special deals, discount, pelayanan yang cepat bahkan diantar ke rumah, dan sebagainya.

Menurut Tiwana (2003) customer relationship management merupakan kombinasi dari proses bisnis dan teknologi yang tujuannya untuk memahami pelanggan dan berbagai prospektif untuk membedakan produk dan jasa perusahaan secara kompetitif. Fokus dari customer relationship management itu sendiri adalah untuk memperbaiki tingkat kepuasan 
pelanggan, meningkatkan minat pelanggan dan meningkatkan pendapatan dari pelanggan yang ada, dalam menghadapi tingginya tingkat persaingan, globalisasi dan perputaran pelanggan serta perkembangan biaya pengakuisisian pelanggan. Dengan diterapkannya CRM, memungkinkan perusahaan untuk memiliki kapabilitas untuk memahami perilaku perubahan pelanggan dengan lebih baik dan untuk nenentukan tipe komunikasi yang bagaimana yang seharusnya dijalankan dalam menghadapi pelanggan. Adapun Komponen Manajemen Hubungan Pelanggan memiliki 3 (tiga) komponen utama menurut Lukas (2006) yang saling berintegrasi, yaitu:
a. Orang (People)
b. Proses (Process
c. Teknologi (Technology)

\section{Etika Perilaku Penjualan}

Etika Perilaku juga dapat didefinisikan sebagai kesesuaian dengan norma sosial, seperti fair play, kejujuran, dan keterbukaan (Roberson dan Anderson, 1993). Selain itu, dalam aspek pemasaran, etika perilaku penjualan dianggap sebagai hubungan timbal balik berdasarkan pertukaran yang adil, dan ketika pelanggan merasakan hubungan yang menguntungkan, maka akan ada umpan balik mungkin akan diambil oleh konsumen.

Román dan Munuera (2005) mendefinisikan etika perilaku penjualan sebagai tindakan yang adil dan jujur yang memungkinkan penjual untuk membina hubungan jangka panjang dengan pelanggan berdasarkan kepuasan pelanggan dan kepercayaan. Penjual biasanya memiliki interaksi pribadi dengan pelanggan dan tindakan mereka lebih mudah terlihat, dimana perilaku yang tidak etis dapat memiliki efek mendalam pada opini publik (Mantel, 2005). Definisi etikan perilaku penjualan terhadap perilaku yang tidak etis didasarkan pada sejauh mana tindakan yang diusulkan dianggap sebagai hak terhadap salah, baik versus jahat, adil dibandingkan adil, atau hanya dibandingkan adil (Roman, 2003).

Perilaku penjualan etis menunjukkan bahwa penjual menyampaikan pesan otentik dalam komunikasi mereka dengan pelanggan, hanya menjual barang barang/jasa yang dapat menguntungkan pelanggan mereka, menjanjikan hanya apa yang bisa diberikan, dan memperlakukan informasi pelanggan sebagai suatu yang rahasia. Dalam prakteknya, dari perspektif penjual, penjual sering berperilaku tidak beretika dalam rangka memenuhi target penjualan, dan seperti etika perilaku penjualan yang tidak etis dapat mengakibatkan argumen dan menghancurkan timbal balik hubungan pembeli-penjual, sehingga perusahaan akan kehilangan pelanggan atau bahkan memiliki konsekuensi lain yang lebih serius. Di sisi lain, dari perspektif pelanggan, kepercayaan pelanggan dalam penjual didasarkan pada persepsi bahwa tenaga penjual konsisten, dapat diandalkan, jujur, kompeten, menyenangkan, dan baik hati (Román dan Ruiz, 2005), dan penjual akan melakukan yang terbaik / nya untuk memberikan manfaat bagi pelanggan (Morgan dan Hunt, 1994) dan 
mengembangkan hubungan yang menguntungkan.

Perilaku penjualan etis adalah membangun sangat sulit dipahami dan pada situasi khusus (Lagace et al., 1991). Namun, perilaku tidak etis penjualan seperti yang dirasakan oleh pelanggan didefinisikan sebagai perilaku tenaga penjual jangka pendek yang memungkinkan dia / dia untuk mendapatkan dengan mengorbankan pelanggan. Contoh kegiatan tersebut meliputi: berbohong atau melebihlebihkan tentang manfaat produk / jasa, ketersediaan, kompetisi, menjual produk / jasa yang tidak membutuhkan orangorang, memberikan jawaban ketika jawabannya adalah tidak benar-benar diketahui, dan menerapkan taktik pengaruh manipulatif tinggi atau teknik jual bertekanan (Cooper dan Frank 2002; Futrell 2002). Perilaku yang tidak etis Seorang tenaga penjual dapat memberikan dampak negatif kepuasan pelanggan dan retensi. Dubinsky et al. (1992) berpendapat bahwa perilaku tidak etis penjual dapat menyebabkan ketidakpuasan pelanggan, miskin wordof-mouth, kehilangan pelanggan, mengurangi penjualan dan laba (Burnett et al., 2008).

Dengan demikian, melalui interaksi yang berulang, hubungan positif antara penjual dan perilaku penjualan etika serta kepercayaan pelanggan dapat dibentuk. Oleh karena itu, pilihan antara perilaku etis dan tidak etis penjualan adalah dilema bagi tenaga penjualan. Ketika pelanggan membeli produk atau jasa yang membutuhkan pengetahuan profesional dan mereka tidak mempunyai kemampuan untuk menilai suatu produk dan hanya mengandalkan pengetahuan dannasihat dari penjual, maka sikap etika perilaku penjualan etika menjadi sangat penting (Wray et al., 1994). Namun, ketika seorang tenaga penjualan yang dinilai tentang kinerja penjualan jangka pendek, ia mungkin berperilaku tidak etis dalam meningkatkan penjualannya, sehingga akan merugikan dalam hubungan jangka panjang dedngan pelanggan.

\section{Hipotesa Penelitian}

Berdasarkan kerangka teori yang telah disebutkan diatas maka hipotesis penelitian adalah :

Hal : Terdapat pengaruh yang signifikan kualitas hubungan dan loyalitas pelanggan terhadap etika perilaku penjualan

Ho1 : Tidak terdapat pengaruh yang signifikan kualitas hubungan dan loyalitas pelanggan terhadap etika perilaku penjualan

Ha2 : Terdapat hubungan yang signifikan antara kualitas hubungan dan loyalitas pelanggan terhadap etika perilaku penjualan

Ho2 : Tidak Terdapat hubungan yang signifikan antara kualitas hubungan dan loyalitas pelanggan terhadap etika perilaku penjualan

\section{Motede Penelitian Jenis Dan Sumber Data}

Data yang digunakan pada penelitian ini adalah :
1. Data Primer 
Data primer yaitu data yang diambil langsung dari objek penelitian berupa data kualitas hubungan dan loyalitas pelanggan serta etika perilaku penjualan yang diperoleh penulis dari responden-responden yaitu tenaga penjual yang ada dengan cara penyebaran kuesioner.

\section{Data Sekunder}

Data sekunder yaitu data yang penulis peroleh dalam bentuk yang sudah jadi, diperoleh dari berbagai sumber baik berupa laporan maupun informasi dari pihak perusahaan ataupun dari pihak lain yang berhubungan berupa data penjualan, sejarah perusahaan.

\section{Populasi dan Sampel}

Adapun metode pngambilan sampel pada penelitian ini menggunakan teknik accidental sampling yaitu responden dipilih pada saat ditemui pada saat dilokasi penelitian. Adapun jumlah responden yang diambil adalah sebanyak 70 orang, dengan catatan bahwa sampel tersebut representatif atau mewakili populasi.

\section{Teknik Analisis Data}

\section{Uji Validitas}

Uji validitas dilakukan untuk mengetahui suatu ukuran yang menunjukan tingkatan-tingkatan kevalida atau kesahihan suatu varabel penelitian, disini penulis menggunakan metode pearson corelation.

\section{Uji Reliabilitas}

Dasar pengambilan keputusan uji reliabilitas adalah jika ..>0,7 maka butir atau variabel tersebut reliabel, sebaliknya jika .. $<0,7$ maka butir atau variabelnya tidak reliabel.

3. Uji Normalitas Data
Uji Normalitas bertujuan untuk menguji apakah dalam model regresi, variabel dependen dengan variabel independen mempunyai distribusi normal atau tidak. Model regresi yang baik adalah distribusi data normal atau mendekati normal.

Pengujian dilakukan dengan melihat penyebaran data (titik) pada sumbu diagonal dari grafik scatter plot, dasar pengambilan keputusannya adalah jika data menyebar disekitar garis diagonal dan mengikuti garis diagonal maka model regresi memenuhi asumsi normalitas. Jika data menyebar jauh dari regresi atau tidak mengikuti arah garis diagonal, maka model regresi tidak memenuhi asumsi normalitas.

4. Uji Asumsi Klasik

Untuk mengetahui apakah hasil estimasi regresi yang dilakukan terbebas dari bisa yang mengakibatkan hasil regresi yang diperoleh tidak valid dan akhirnya hasil regresi tersebut tidak dapat dipergunakan sebagai dasar untuk menguji hipotesis dan penarikan kesimpulan, maka digunakan asumsi klasik. Tiga asumsi klasik yang perlu diperhatikan adalah:

a) Uji Multikolonearitas

Tujuan utama adalah untuk menguji apakah pada model regresi ditemukan adanya korelasi antar variabel independen digunakan untuk mendeteksi ada tidaknya multikolonieritas dalam penelitian adalah dengan menggunakan Variance Inflation Factor (VIF) yang merupakan kebalikan $\mathrm{R}^{2}$ (koefesien determinasi). Bila korelasi kecil artinya menunjukkan nilai VIF akan besar. Bila VIF >10 maka dianggap ada multikolonieritas dengan variabel bebas 
lainnya. Sebaliknya VIF $<10$ maka dianggap tidak terdapat multikolonearitas.

b) Uji Autokorelasi

Autokorelasi bertujuan untuk menguji apakah dalam sebuah model regresi linear ada korelasi antara kesalahan pengganggu pada periode $t$. Jika ada, berarti terdapat Autokorelasi. Jika D - W di atas 2 berarti terdapat Autokorelasi negatif.

c) Uji Heterokedastisitas

Pengujian Heterokedastisitas dalam model regresi untuk mengetahui apakah dalam model regresi terjadi ketidaksamaan varians dan dari suatu pengamatan yang lain. Model regresi yang baik adalah tidak terjadi heterokedastisitas.

5. Uji Regresi Berganda

Dalam penelitian ini menggunakan analisis Deskriftif kuantitatif Data yang diperoleh dengan cara memberikan pertanyaan kepada konsumen sebanyak 120 orang responden yang langsung dijadikan sampel. Selanjutnya data yang diperoleh ditabulasikan untuk dilakukan analisa secara Kuantitatif. Dengan menggunakan regresi linear berganda, dengan rumus :

keterangan :

$$
\mathrm{Y}=\mathrm{a}+\mathrm{b}_{1} \mathrm{X}_{1}+\mathrm{b}_{2} \mathrm{X}_{2}+\mathrm{e}
$$

Y : Etika Perilaku Penjualan

$\mathrm{X}_{1}$ : Kualitas Hubungan

$\mathrm{X}_{2} \quad$ : Loyalitas Pelanggan

$\mathrm{B}_{1}-\mathrm{b}_{2}$ : Koefisien Regresi Parsial

\section{Uji F}

Untuk mengetahui pengaruh variable bebas secara bersama-sama terhadap variable terikat, maka dilakukan uji $\mathrm{F}$ dengan cara membandingkan antara $\mathrm{F}$ hitung dengan $F$ tabel pada tingkat signifikan 5\%.

Kriteria pengujian adalah $\mathrm{Ho}$ diterima apabila Fhitung < Ftabel, Ha diterima apabila Fhitung $>$ Ftabel.

7. Uji t

Uji $\mathrm{t}$ menunjukan seberapa jauh pengaruh suatu variabel independent secara individual dalam menerangkan variabel devenden. Uji ini dilakukan secara terpisah-pisah untuk melihat pengaruh masing-masing variabel indevenden terhadap variabel devendennya. Uji t dilakukan dengan cara membandingkan $t$ hitung dengan $t$ table pada tingkat signifikan 5\% jika thitung > t table maka variabel bebas dapat menerangkan terikatnya. Dan artinya variabel bebas ada pengaruhnya terhadap variabel terikatnya.

Kriteria pengujian adalah Ho diterima apabila thitung $<t$ tabel. Ha diterima apabila thitung > ttabel.

Kategori yang digunakan berdasarkan skala likers, dimana responden diminta untuk menjawab pertanyaan dengan nilai jawaban seperti dibawah ini:

1.alternatif jawaban A diberi nilai 5

2. Alternatif jawaban B diberi nilai 4

3. Alternatif jawaban $\mathrm{C}$ diberi nilai 3

4. Alternatif jawaban D diberi nilai 2

5. alternative jawaban $\mathrm{E}$ diberi nilai 1 Untuk taraf signifikan, penulisan menggunakan taraf signifikan sebesar 5\% $(0,05)$ sedangkan untuk memudahkan dalam mengelolah dan menganalisa data penelitian ini, penulis menggunakan program SPSS windows

8. Koefisien Korelasi 
Untuk mengukur sejauh mana pengaruh brand equity terhadap loyalitas pelanggan dalam membeli sepeda motor merek Honda pada PT.Mitra Pinasthika Mustika Motor Pekanbaru digunakan analisis korelasi (r).

Untuk mengetahui besarnya kontribusi variabel $\mathrm{X}$ terhadap variabel $\mathrm{Y}$ digunakan uji Koefisien Determinasi $\left(\mathrm{R}^{2}\right)$. Koefisien determinasi $\left(\mathrm{R}^{2}\right)$ yang menunjukkan seberapa besar perubahan variabel dependent (Loyalitas Pelanggan) dapat dipengaruhi oleh variabel independent (Brand Equity). nilai koefisien determinasi adalah antara 0 (nol) dan 1 (satu). Jika $\left(\mathrm{R}^{2}\right)$ kecil maka kemampuan variabel independent dalam menjelaskan varaiabel dependent sangat terbatas.

9. Uji Koefisien Determinasi $\left(\mathrm{R}^{2}\right)$

Uji koefisien determinasi $\left(\mathrm{R}^{2}\right)$ digunakan untuk mengukur seberapa besar variasi dalam variabel independen mampu menjelaskan bersama-sama variabel dependen atau seberapa baik model regresi yang telah dibuat tersebut cocok dengan data. Semakin besar koefisien determinasinya, maka semakin baik variabel independen dalam menjelaskan variabel dependennya.

Untuk mengetahui variabel independen mana yang paling berpengaruh terhadap variabel dependennya dapat dilihat dari koefisien korelasi parsialnya. Variabel independen yang paling berpengaruh terhadap variabel dependen dilihat dari koefisien korelasi yang paling besar.

\section{Deskripsi Karakteristik Responden}

Deskripsi karakteristik dari responden dalam panelitian ini meliputi usia, jenis kelamin, pendidikan, dan lama bekerja. Untuk lebih jelasnya dapat dilihat pada tabel-tabel berikut ini:

\section{Deskripsi Responden Berdasarkan Jenis Kelamin}

Tabel 4.1: Karakteristik Responden Berdasarkan Jenis Kelamin

\begin{tabular}{|c|c|c|}
\hline $\begin{array}{c}\text { Jenis } \\
\text { Kelamin } \\
\text { Responden }\end{array}$ & $\begin{array}{c}\text { Jumlah } \\
\text { Responden } \\
\text { (orang) }\end{array}$ & $\begin{array}{c}\text { Persen- } \\
\text { tase }(\%)\end{array}$ \\
\hline Laki-Laki & 47 & 67,1 \\
\hline Perempuan & 23 & 32,9 \\
\hline Total & 70 & 100 \\
\hline
\end{tabular}

Sumber Data : Primer diolah 2014

Berdasarkan pada tabel Karakteristik Responden Berdasarkan jenis kelamin tersebut, maka diketahui bahwa dominasi responden laki-laki lebih mendominasi dari pada responden perempuan, yaitu: $67,1 \%$ responden adalah laki-laki, dan $32,9 \%$ adalah responden perempuan. Dominasi sampel laki-laki ini, karena pada umumnya perusahaaan leasing lebih banyak mempekerjakan karyawan laki-laki

\section{Deskripsi Responden Berdasarkan Usia}

Tabel 4.2: Karakteristik Responden Berdasarkan Usia Responden

\begin{tabular}{|c|c|c|}
\hline $\begin{array}{c}\text { Usia } \\
\text { Responden } \\
\text { (Th) }\end{array}$ & $\begin{array}{c}\text { Jumlah } \\
\text { responden } \\
\text { (orang) }\end{array}$ & $\begin{array}{c}\text { Persentase } \\
(\%)\end{array}$ \\
\hline $20-25$ & 23 & 32,9 \\
\hline $25-30$ & 19 & 27,1 \\
\hline $30-35$ & 17 & 24,3 \\
\hline $35-40$ & 7 & 10 \\
\hline $40+$ & 4 & 5,7 \\
\hline Total & 70 & 100 \\
\hline
\end{tabular}

Sumber: Data Primer Diolah, 2014 98 
Pada tabel tersebut dapat dilihat bahwa dari 70 responden yang dikelompokkan berdasarkan 5 tingkatan usia, diketahui bahwa kelompok usia 20 s/d 25 tahun memiliki jumlah sampel sebanyak 23 orang sebesar 32,9\%, yang mana pada kelompok ini merupakan responden yang mendominasi dari seluruh responden berdasarkan tingkatan usia. Sedangkan yang paling sedikit ada pada usia 40 tahun keatas sebanyak 4 orang atau $5,7 \%$ dari total responden.

Banyaknya salesman muda yang bekerja pada sector leasing ini disebabkan perkembangan leasing di Pekanbaru yang semakin banyak sehingga kebutuhan akan tenaga kerja juga semakin meningkat. Dengan banyaknya tenaga salesman leasing yang berusia muda ini maka perusahaan leasing harus semakin ketat menjaga kualitas hubungan dengan pelanggan dan memberikan keahlian salesman mereka dalam etika perilaku penjualan.

\section{Deskripsi Responden Berdasarkan Pendidikan}

Untuk mengetahui kemampuan salesman dalam melakukan hubungan penjualan dengan pelanggan dan loyaitas pelanggan Berikut disajikan tabel responden berdasarkan pendidikan.

Tabel 4.3: Karakteristik Responden Berdasarkan Pendidikan

\begin{tabular}{|l|c|c|}
\hline Pendidikan & $\begin{array}{c}\text { Jumlah } \\
\text { Responden } \\
\text { (orang) }\end{array}$ & $\begin{array}{c}\text { Persentase } \\
(\%)\end{array}$ \\
\hline SMA & 12 & 17,2 \\
\hline DIII & 37 & 52,8 \\
\hline
\end{tabular}

\begin{tabular}{|c|c|c|}
\hline S1 (sarjana) & 21 & 30 \\
\hline S2 dan S3 & - & - \\
\hline Total & & $100 \%$ \\
\hline
\end{tabular}

Sumber: Data Primer Diolah, 2014

\section{Deskripsi Responden Berdasarkan Lama Bekerja}

Berikut disajikan lamanya responden dalam bekerja di sector leasing ini mempunyai lama bekerja 1 s/d 3 lima tahun sebanyak 37 orang atau 52,8 persen dan mendominasi sebagai responden terbanyak. Sedangkan yang paling sedikit adalah yang mempunyai lama bekerja 15 tahun lebih sebesar 2,9 persen atau dua orang. Maka dengan jumlah pengalaman kerja yang rendah ini maka para salesaman akan semakin rawan dalam melakukan tindakan yang etis dalam berperilaku penjualan.

Tabel 4.4: Karakteristik Responden Berdasarkan Lama Bekerja

\begin{tabular}{|c|c|c|}
\hline $\begin{array}{c}\text { Lama } \\
\text { bekerja } \\
\text { (th) }\end{array}$ & $\begin{array}{c}\text { Jumlah } \\
\text { Responden } \\
\text { (orang) }\end{array}$ & $\begin{array}{c}\text { Persentase } \\
(\%)\end{array}$ \\
\hline $1-5$ & 37 & 52,8 \\
\hline $5-10$ & 19 & 27,2 \\
\hline $10-15$ & 12 & 17,1 \\
\hline $15+$ & 2 & 2,9 \\
\hline Total & 70 & $100 \%$ \\
\hline
\end{tabular}

Sumber: Data Primer Diolah, 2014

\subsection{Uji Validitas}

Pada program Statistical Product and Service Solution (SPSS) teknik pengujian yang digunakan validitas adalah dengan menggunakan korelasi. Dalam penelitian ini untuk mengetahui valid suatu variabel dilakukan pengujian dengan menggunakan teknik Validity analysis dengan nilai korelasi. 
Berdasarkan perhitungan nilai korelasi person dari setiap item pernyataan dalam setiap variabel, maka dapat dilihat bahwa setelah dilakukan uji validitas semua item masing-masing variabel (Store Atmosphere, Store Image, Keputusan Pembelian Ulang), maka hasilnya $\mathrm{r}_{\text {hitung }}>\mathrm{r}$ tabel $(\mathrm{df}: 70=$ 0.2017). Dengan demikian dapat disimpulkan bahwa semua item masingmasing variabel memenuhi syarat untuk valid.

Pada hasil perhitungan terhadap nilai Cronbach's Alpha, maka dapat dilihat bahwa nilai Cronbach's Alpha masing-masing variabel adalah sebagai berikut: Kualitas Hubungan $\left(\mathrm{X}_{1}\right)(0$. 689), Loyalitas Pelanggan $\left(\mathrm{X}_{2}\right)(0.665)$, dan Etika Perilaku Penjualan (0.633). Dengan demikian dapat dikatakan bahwa semua variabel tersebut adalah reliable, karena memilki nilai Cronbach's Alpha di atas 0,90 .

\section{Uji Normalitas}

Untuk mendeteksi normalitas, maka dapat dilihat dengan menggunakan grafik normal P-P Plot Of Regression Standarized Residual. Pada gambar terlihat titik-titik menyebar di sekitar garis diagonal, serta penyebarannya mengikuti arah garis diagonal, maka model regresi memenuhi asumsi normalitas.

\section{Uji Reliability}

Dalam pengujian ini Batasan nilai adalah 0,6. Jika nilai reliabilitas kurang dari 0,6 maka nilainya kurang baik. Nilai reliabilitas dalam uji ini adalah pada kolom Reliabilitiy Statistics (Cronbach's Alpha). Dan diketahui nilai reliabilitas ke lima variabel berada diatas angka 0,6. Artinya adalah bahwa alat ukur yang digunakan dalam penelitian ini reliable atau dapat dipercaya.

Uji normalitas adalah langkah awal yang harus dilakukan untuk setiap analisis multiviate khususnya jika tujuannya adalah inferensi. Jika terdapat normalitas, maka residual akan teritribusi secara normal. Setelah melihat gambar hasil dari pengolahan data dengan menggunakan SPSS for windows 17.00, maka dapat dikatakan bahwa semua residual yang ada dalam penelitian ini terdisitribusi secara normal.

\section{Uji Asumsi Klasik \\ Uji Autokorelasi}

Uji autokorelasi ini dilakukan dengan menggunakan metode DurbinWatson (DW). berdasarkan hasil perhitungan data dengan menggunakan program SPSS 17.00 for windows, maka didapatkan hasil Durbin-Watson (DW) seperti pada tabel di bawah ini: 
Tabel 4.8.1. : hasil uji Autokorelasi

\begin{tabular}{|c|c|c|c|c|c|c|c|c|c|c|}
\hline \multirow[b]{3}{*}{ Model } & \multicolumn{9}{|c|}{ Model Summary } & \multirow[b]{3}{*}{$\begin{array}{c}\text { Durbi } \\
\text { n- } \\
\text { Watso } \\
n\end{array}$} \\
\hline & & \multirow[b]{2}{*}{$\begin{array}{c}\mathrm{R} \\
\text { Squar } \\
\mathrm{e}\end{array}$} & \multirow[b]{2}{*}{$\begin{array}{c}\text { Adjuste } \\
\text { d R } \\
\text { Square }\end{array}$} & \multirow{2}{*}{\begin{tabular}{|c|} 
Std. \\
Error of \\
the \\
Estimat \\
$\mathrm{e}$
\end{tabular}} & \multicolumn{5}{|c|}{ Change Statistics } & \\
\hline & & & & & $\begin{array}{l}\text { R Square } \\
\text { Change }\end{array}$ & $\begin{array}{c}\mathrm{F} \\
\text { Chang } \\
\mathrm{e}\end{array}$ & df1 & df2 & $\begin{array}{c}\text { Sig. F } \\
\text { Change }\end{array}$ & \\
\hline 1 & .814 & .662 & .655 & 2.25180 & .662 & $\begin{array}{r}91.05 \\
3\end{array}$ & 2 & 93 & .000 & 1.628 \\
\hline
\end{tabular}

a. Predictors: (Constant), Kualitas Hubungan, Loyalitas Pelanggan

b. Dependent Variable: keputusan.pembelian.ulang

Sumber: data primer diolah, 2014

Berdasarkan hasil olah data yang terdapat pada tabel di atas, diperoleh nilai Durbin-Watson sebesar 1,628. Nilai ini berada antara -2 sampai +2 , berarti tidak terdapatnya autokorelasi.

\section{Uji Multikolinearitas}

Hasil Uji Multikolinearitas disimpulkan seperti tabel berikut ini:

Tabel. 4.8.2: Uji Multikolinearitas

\section{Coefficients $^{\text {a }}$}

\begin{tabular}{|c|c|c|c|c|c|c|c|c|c|c|}
\hline \multirow[b]{2}{*}{ Model } & \multicolumn{2}{|c|}{$\begin{array}{l}\text { Unstandardiz } \\
\text { ed } \\
\text { Coefficients }\end{array}$} & \multirow{2}{*}{$\begin{array}{c}\begin{array}{c}\text { Standardize } \\
\mathrm{d} \\
\text { Coefficients }\end{array} \\
\text { Beta }\end{array}$} & \multirow[b]{2}{*}{$\mathrm{t}$} & \multirow[b]{2}{*}{ Sig } & \multicolumn{3}{|c|}{ Correlations } & \multicolumn{2}{|c|}{$\begin{array}{l}\text { Collinearit } \\
\text { y Statistics }\end{array}$} \\
\hline & B & $\begin{array}{l}\text { Std. } \\
\text { Error }\end{array}$ & & & & $\begin{array}{c}\text { Zero } \\
- \\
\text { order }\end{array}$ & $\begin{array}{c}\text { Partia } \\
1\end{array}$ & $\begin{array}{c}\text { Par } \\
\mathrm{t}\end{array}$ & $\begin{array}{c}\text { Tole } \\
\text { ranc } \\
\mathrm{e}\end{array}$ & VIF \\
\hline 1 (Constant) & 2.781 & 1.111 & & 2.50 & .01 & & & & & \\
\hline $\begin{array}{l}\text { Kualitas } \\
\text { Hubungan }\end{array}$ & .417 & .114 & .410 & $\begin{array}{r}3.65 \\
7\end{array}$ & $\begin{array}{r}.00 \\
0\end{array}$ & .779 & .355 & & .290 & \\
\hline $\begin{array}{l}\text { Loyalitas } \\
\text { Pelanggan }\end{array}$ & .437 & .112 & .438 & $\begin{array}{r}3.90 \\
8\end{array}$ & $\begin{array}{r}.00 \\
0\end{array}$ & .783 & .376 & $\begin{array}{r}.23 \\
6\end{array}$ & .290 & 3.45 \\
\hline
\end{tabular}

a. Dependent Variable: Etika Perilaku Pembelian

Sumber: data primer diolah, 2014 
Pada tabel tersebut terlihat bahwa variabel kualitas hubungan mempunyai nilai VIF, 3.453, dan variabel loyalitas pelanggan mempunyai nilai VIF 3.453. Dengan melihat nilai Semua Variabel bebas $<10$ dan tolerance $>0,10$. Berarti hal itu menyatakan bebas dari asumsi multikolinearitas.

\section{Uji Heteroskedastisitas}

Deteksi heteroskedastisitas dapat dengan melihat grafik scatterplot. Deteksinya dengan melihat ada tidaknya pola tertentu pada grafik dimana sumbu $\mathrm{X}$ dan $\mathrm{Y}$ menyebar diatas dan dibawah angka 0 pada sumbu $Y$.

Pada penelitian ini model regresi ini tidak terjadi gejala heteroskedastisidas.

\section{Uji Hipotesis}

Uji Regresi Linear Berganda

Penelitian ini menggunakan regresi linear berganda, dilakukan dengan menggunakan metode enter, dimana semua variabel dimasukkan untuk mencari pengaruh variabel independen terhadap variabel dependen melalui meregresikan Etika Perilaku Penjualan sebagai variabel dependen dan Kualitas Hubungan dan Loyalitas Pelanggan sebagai variabel independen. Hasil hipotesis seperti yang tercantum dalam tabel berikut ini:

\section{Gambar 2: Scatterplot}

\section{Scatterplot}

\section{Dependent Variable: etika.perilaku.penjualan}

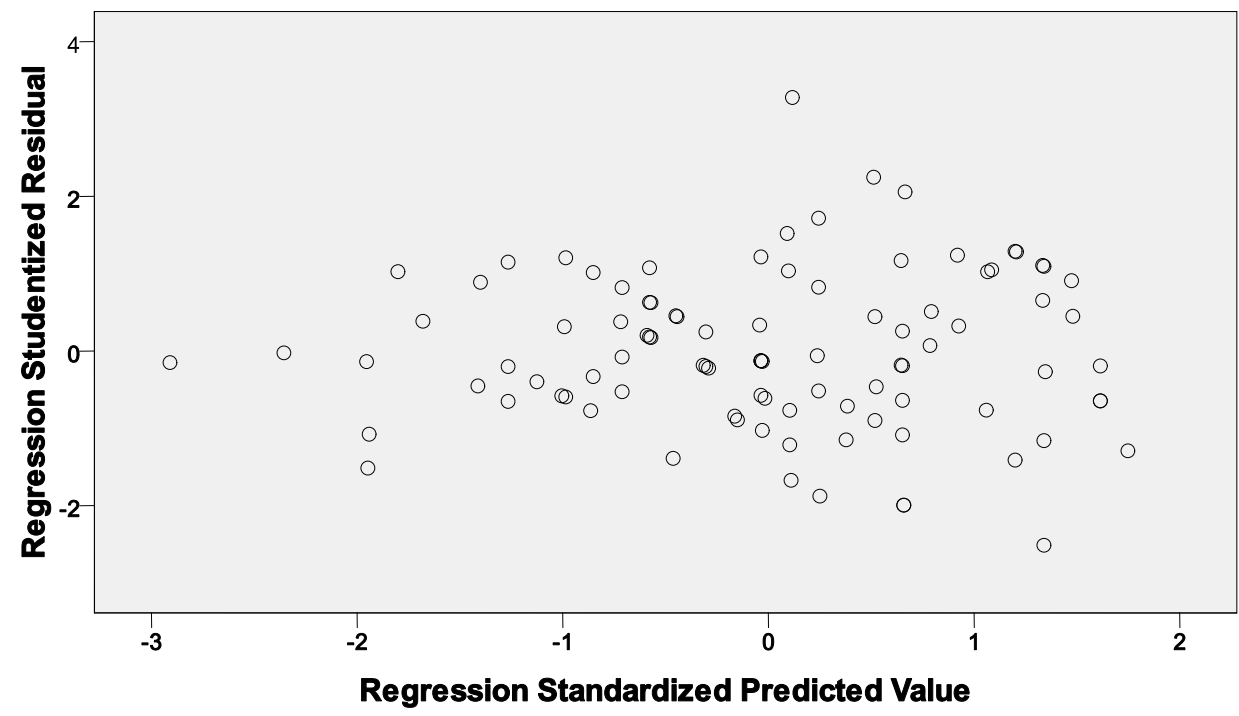


Sumber: data primer diolah, 2014

\section{Hasil Uji Regresi}

\section{Coefficients $^{\mathrm{a}}$}

\begin{tabular}{|c|c|c|c|c|c|c|c|c|c|c|}
\hline \multirow[b]{2}{*}{ Model } & \multicolumn{2}{|c|}{$\begin{array}{l}\text { Unstandardiz } \\
\text { ed } \\
\text { Coefficients }\end{array}$} & $\begin{array}{c}\text { Standardize } \\
\mathrm{d} \\
\text { Coefficients }\end{array}$ & \multirow[b]{2}{*}{$\mathrm{t}$} & \multirow[b]{2}{*}{ Sig } & \multicolumn{3}{|c|}{ Correlations } & \multicolumn{2}{|c|}{$\begin{array}{l}\text { Collinearit } \\
\text { y Statistics }\end{array}$} \\
\hline & B & $\begin{array}{l}\text { Std. } \\
\text { Error }\end{array}$ & Beta & & & $\begin{array}{c}\text { Zero } \\
- \\
\text { order }\end{array}$ & $\begin{array}{c}\text { Partia } \\
1\end{array}$ & $\begin{array}{c}\text { Par } \\
\mathrm{t}\end{array}$ & $\begin{array}{c}\text { Tole } \\
\text { ranc } \\
\mathrm{e}\end{array}$ & VIF \\
\hline (Const & 2.781 & 1.111 & & $\begin{array}{r}2.50 \\
2\end{array}$ & \begin{tabular}{|r|}
.01 \\
4 \\
\end{tabular} & & & & & \\
\hline $\begin{array}{l}\text { Kualitas } \\
\text { Hubungan }\end{array}$ & .417 & .114 & .410 & $\begin{array}{r}3.65 \\
7\end{array}$ & $\begin{array}{r}.00 \\
0\end{array} \mid$ & .779 & .355 & $\begin{array}{r}.22 \\
0\end{array}$ & .290 & 3.4 \\
\hline $\begin{array}{l}\text { Loyalitas } \\
\text { Pelanggan }\end{array}$ & .437 & .112 & .438 & $\begin{array}{r}3.90 \\
8\end{array}$ & $\begin{array}{r}.00 \\
0\end{array}$ & .783 & .376 & $\begin{array}{r}.23 \\
6\end{array}$ & .290 & 3.45 \\
\hline
\end{tabular}

a. Dependent Variable: Etika Perilaku Penjualan

\section{Sumber: data primer diolah, 2014}

Persamaan regresi dari hasil perhitungan statistik didapat sebagai berikut:

$$
\mathrm{Y}=\mathrm{a}+\mathrm{b}_{1} \mathrm{X}_{1}+\mathrm{b}_{2} \mathrm{X}_{2}+\mathrm{e}
$$$$
\mathrm{Y}=\mathbf{2 . 7 8 1}+0.471 \mathrm{X} 1+0.437 \mathrm{X}_{2}+\mathrm{e}
$$

Dari persamaan tersebut diatas maka didapat nilai konstansta sebesar 2.781 yang berarti jika variabel lainnya diangggap konstan maka nilai dari variable etika perilaku penjualan adalah sebesar 2.781 satuan. Sedangkan koefisien regresi sebesar 0.471 berarti bahwa kenaikan setiap 1 satuan kualitas hubungan maka akan menaikkan sebesar 0.471satuan etika perilaku penjualan. Untuk koefisien regresi 0.437 berarti setiap kenaikan 1 satuan loyalitas pelanggan maka akan menaikkan etika perilaku penjualan sebesar 0.437 . Sedangkan Standar error $(e)$ merupakan variabel acak dan mempunyai distribusi probabilitas. Standar error (e) mewakili semua faktor yang mempunyai pengaruh terhadap Y tetapi tidak dimasukan dalam persamaan.

\section{Pengujian Hipotesis Uji F (Secara Simultan)}

Untuk membuktikan hal tersebut, maka dilakukan uji $\mathrm{F}$. hasil uji regresi secara simultan atau uji $\mathrm{F}$ dapat dilihat pada tabel berikut ini:

Tabel 4.11: Hasil Uji F Hitung 


\begin{tabular}{|ll|r|r|r|r|r|}
\hline \multicolumn{2}{|l|}{ ANOVA $^{\mathbf{b}}$} \\
\hline 1 & Sum of & Squares & df & Mean Square & F & Sig. \\
\hline Regression & 923.392 & 2 & 461.696 & 91.053 & $.000^{\mathrm{a}}$ \\
& Residual & 471.567 & 93 & 5.071 & & \\
Total & 1394.958 & 95 & & & \\
\hline
\end{tabular}

a. Predictors: (Constant), Kualitas Hubungan, Loyalitas Pelanggan

b. Dependent Variable: etika perilaku penjualan

\section{Sumber: data primer diolah, 2014}

Pada tabel hasil pengujian hipotesis menunjukkan bahwa nilai $\mathrm{F}_{\text {hitung }}(91.053)>\mathrm{F}_{\text {tabel (2:93) }}$ (3.09) dengan sig $(0,000)<0,005$. Dengan demikian, maka $\mathrm{H}_{\mathrm{o}}$ ditolak dan $\mathrm{H}_{\mathrm{a}}$ diterima. Hal ini menunjukkan bahwa Kualitas Hubungan dan Loyalitas Pelanggan secara bersamasama berpengaruh signifikan terhadap etika perilaku penjualan.

Dari tabel hasil uji t, maka dapat dilihat masing-masing nilai $\mathrm{t}$ hitung dan signifikansi variabel bebas. Diketahui nilai t tabel (uji 2 sisi pada signifikansi $5 \%$ ) dengan persamaan $\mathrm{n}-\mathrm{k}-1$; alpa $/ 2=$ $96-2-1 ; 0.05 / 2=93 ; 0.025=1.985$. dengan demikian didapatkan hasil sebagai berikut:

1. Diketahui $\mathrm{t}$ hitung (3.657) $>\mathrm{t}$ tabel (1.985). Artinya variabel Kualitas hubungan berpengaruh signifikan

\section{Pengujian Hipotesis Uji T (Secara Parsial )}

Untuk mengetahui hal itu perlu dilakukan penelitian lebih lanjut dengan menggunakan uji t statistik. Berikut tabel hasil uji t tersebut:

terhadap etika perilaku penjualan.

2. Diketahui $\mathrm{t}$ hitung $(3.908)>\mathrm{t}$ tabel (1.985). Artinya variabel loyalitas pelanggan berpengaruh signifikan terhadap etika perilaku penjualan.

\section{Uji Koefisien Determinasi $\mathbf{R}^{2}$ dan Korelasi R}

Pengujian hipotesis dengan menggunakan koefisien determinasi $\left(\mathrm{R}^{2}\right)$ bertujuan untuk mengetahui persentase variabel independen secara bersamasama dapat menjelaskan variabel dependen. 
Tabel 4.13: Uji Koefisien Determinasi dan Korelasi

\begin{tabular}{|c|c|c|c|c|c|c|c|c|c|c|}
\hline \multirow[b]{3}{*}{ Model } & \multicolumn{9}{|c|}{ Model Summary } & \multirow[b]{3}{*}{$\begin{array}{c}\text { Durbi } \\
\text { n- } \\
\text { Watso } \\
n\end{array}$} \\
\hline & & \multirow[b]{2}{*}{$\begin{array}{c}\mathrm{R} \\
\text { Squar } \\
\mathrm{e}\end{array}$} & \multirow[b]{2}{*}{$\begin{array}{c}\text { Adjuste } \\
\text { d R } \\
\text { Square }\end{array}$} & \multirow{2}{*}{\begin{tabular}{|c|} 
Std. \\
Error of \\
the \\
Estimat \\
$\mathrm{e}$
\end{tabular}} & \multicolumn{5}{|c|}{ Change Statistics } & \\
\hline & & & & & $\begin{array}{l}\text { R Square } \\
\text { Change }\end{array}$ & $\begin{array}{c}\mathrm{F} \\
\text { Chang } \\
\mathrm{e}\end{array}$ & df1 & df2 & $\begin{array}{c}\text { Sig. F } \\
\text { Change }\end{array}$ & \\
\hline 1 & .814 & .662 & .655 & 2.25180 & .662 & $\begin{array}{r}91.05 \\
3\end{array}$ & 2 & 93 & .000 & 1.628 \\
\hline
\end{tabular}

a. Predictors: (Constant), Kualitas Hubungan, Loyalitas Pelanggan

b. Dependent Variable: etika perilaku penjualan

Sumber: data primer diolah, 2014

Dari tabel tersebut diatas dan berdasarkan ketentuan kuat tidaknya pengaruh yang telah dijelaskan pada bagian sebelumnya, dapat dijelaskan sebagai berikut:

Nilai R Squaere pada tabel diatas 0.662 yang menunjukkan bahwa Variabel Etika perilaku penjualan dipengaruhi oleh Variabel kualitas hubungan dan loyalitas pelanggan sebesar $66.2 \%$ sedangkan sisanya $33.8 \%$ dipengaruhi oleh faktorfaktor yang tidak diteliti oleh peneliti.

Nilai $\mathrm{R}$ pada tabel diatas adalah sebesar 0. 814 yang menunjukkan bahwa terdapat pengaruh yang sangat kuat dimana variabel kualitas hubungan dan loyalitas pelanggan secara bersama-sama mempengaruhi Etika perilaku penjualan sebesar $81.4 \%$.

\section{PENUTUP}

1. Dari uji validitas didapatkan hasil bahwa seluruh pertanyaan yang menjadi variabel penelitian yang disebar kepada responden dinyatakan valid, nilai $r$ tabel sebesar 0.2017 .
2. Uji realibilitas terhadap keseluruhan variabel didapatkan hasil Kualitas Hubungan $\left(\mathrm{X}_{1}\right)$ (0. 689), Loyalitas Pelanggan $\left(\mathrm{X}_{2}\right)(0.665)$, dan Etika Perilaku Penjualan (0.633). Dengan demikian dapat dikatakan bahwa semua variabel tersebut adalah reliable.

3. Uji normalitas data dengan menggunakan uji kosmogorovsmirnov, model regresi memenuhi asumsi normalitas. Variabel minat nasabah, kemudahan pelayanan, sistem syariah, promosi, budaya secara statistik telah terdistribusi secara normal dan layak untuk dijadikan sebagai data penelitian

4. Uji Asumsi Klasik menunjukkan bahwa tidak terdapat autokorelasi karena memiliki nilai 1,628 , sedangkan dari hasil uji multikolinearitas terlihat nilai Semua Variabel bebas $<10$ dan tolerance $>0,10$. Berarti hal itu menyatakan bebas dari asumsi multikolinearitas dan dari uji heterosdesitas didapat hasil tidaknya adanya pola tertentu 
pada grafik dimana sumbu $\mathrm{X}$ dan $\mathrm{Y}$ menyebar diatas dan dibawah angka 0 pada sumbu yang berarti tidak terdapat heterosdesitas.

5. Dari uji linier berganda didapat hasil $: Y=2.781+0.471 X 1+0.437 X_{2}+e$

6. Pengujian dengan uji $\mathrm{F}$ didapat hasil pengujian yang menunjukkan bahwa nilai $\mathrm{F}_{\text {hitung }}(91.053)>\mathrm{F}_{\text {tabel }}(2: 93)$ (3.09) dengan sig $(0,000)<0,005$. Dengan demikian, maka $\mathrm{H}_{\mathrm{o}}$ ditolak dan $\mathrm{H}_{\mathrm{a}}$ diterima. Hal ini menunjukkan bahwa Kualitas Hubungan dan Loyalitas Pelanggan secara bersama-sama berpengaruh signifikan terhadap etika perilaku penjualan.

7. Dari uji $\mathrm{t}$ didapat hasil $\mathrm{t}$ hitung (3.657) $>\mathrm{t}$ tabel (1.985). Artinya variabel Kualitas hubungan berpengaruh signifikan terhadap etika perilaku penjualan, kemudain $\mathrm{t}_{\text {hitung }}$ (3.908) $>\mathrm{t}$ tabel (1.985). Artinya variabel loyalitas pelanggan berpengaruh signifikan terhadap etika perilaku penjualan.

8. Dari Uji R Square terlihat hasil Nilai $\mathrm{R}$ Squaere pada tabel diatas 0.662 yang menunjukkan bahwa Variabel Etika perilaku penjualan dipengaruhi oleh Variabel kualitas hubungan dan loyalitas pelanggan sebesar $66.2 \%$ sedangkan sisanya $33.8 \%$ dipengaruhi oleh faktor-faktor yang tidak diteliti oleh peneliti. Sedangkan korelasi Nilai $R$ pada tabel diatas adalah sebesar 0. 814 yang menunjukkan bahwa terdapat pengaruh yang sangat kuat dimana variabel kualitas hubungan dan loyalitas pelanggan secara bersama-sama mempengaruhi
Etika perilaku penjualan sebesar $81.4 \%$.

\section{Saran}

1. Perusahaan leasing harus dapat meningkatkan kualitas hubungan yang semakin dekat pelanggannya dalam membina hubungan jangka panjang yang dapat dilakukan dengan cara : gathering pelanggan, memberikan hadiah, mengingatkan hari bersejarah kepada pelanggan. Karena dengan kualitas hubungan yang baik ini akan memberikan keuntungan masa depan bagi perusahaann.

2. Dalam meningkatkan loyalitas pelanggan maka perusahaan leasing harus memperhatikan saran dari pelanggan yang dianggap sebagai sahabat dengan menyediakan kotak saran maupun menemui langsung kepada pelanggan tersebut.

3. Dalam upaya meningkatkan etika perilaku penjualan bagi perusahaan leasing harus dapat mencermati perilaku dari tenaga penjual ketika melakukan hubungan dengan pelanggan sehingga dapat menghindari perilaku nyang tidak etis dari tenaga penjual terhadap pelanggan, dengan caranya adalah melakukan pemeriksaan ulang kepada pelanggan.

\section{DAFTAR PUSTKA}

Alrubaiee, L., \& Alkaa,ida, F. (2011). The mediating effect of Patient satisfaction in the Patients' perceptions of healthcare quality Patient trust relationship. International Journal of Marketing 
Studies, Vol. 3, No. 1; February, 103-127

Anderson, J. C., \& Narus, J. A. (1990). A model of distributor firm and manufacturer firm working partnerships. Journal of Marketing, 54, 42-58. http://dx.doi.org/10.2307/1252172

Burnett, .M., Pettijohn, C., and Keith, N. (2008). A Comparison of the Ethical Perceptions prospective personal selling and advertising employees. The Marketing Management Journal, 18, 1, 77- 83.

Buttle,Francis. (2007). Customer

Relationship Management:

Terjemahan Arief Subiyanto.

Penerbit Bayumedia Publising: Jakarta.

Carpenter, Jason M. and Ann Fairhurst (2005), "Consumer shopping value, satisfaction, and loyalty for retail apparel brands," Journal of Fashion Marketing and management, Vol. 9 No.3, pp. 256-269.

Chaffey (2006) Effective Customer Relationship Management through e-CRM, Journal of Business Ethics, 13 (August), 637-647. http://dx.doi.org/10.1007/BF008718 11

Cooper, R.W., \& Frank, G.L. (2002). Ethical challenges in the two main segments of the insurance industry: Key considerations in the evolving financial services marketplace. Journal of Business Ethics, 36(1/2), 5-20.

http://dx.doi.org/10.1023/A:101423 $\underline{5908833}$

Dubinsky, Alan J., Marvin A. Jolson, Ronald E. Michaels, Masaaki
Kotabe and Chae Un Lim. (1992). Ethical Perceptions of Field Sales Personnel: An Empirical Assessment. Journal of Personal Selling and Sales Management, Vol. XII (Fall), pp. 9-21.

Futrell, C.M. (2002). Fundamentals of selling: Customers for life (7th ed.). New York: McGraw-Hill.

Griffin, Michael., 2009, "Customer Relationship Management (CRM) Metrics: What's the Holdup", Journal International Journal of Enterprise Information Systems (IJEIS)., Volume 2

Hassan, 2008, Perilaku Tenaga Penjual, PT. Andi Offset, Yogyakarta

Kotler Philip. 2004. Manajemen Pemasaran. PT. Prehallindo. Jakarta.

Mantel, Susan Powell (2005). Choice or perception: How affect influences choices among salespeople. Journal of Personal Selling \& Sales Management, Vol. XXV, No. 1, (Winter 2005), pp. 43-55.

Morgan, R.M., and Hunt, S.D. (1994). The commitment - trust theory of relationship marketing. Journal ofMarketing, Vol. 58(3), pp. 20-38. http://dx.doi.org/10.2307/1252308

Román, Sergio (2003). The Impact of Ethical Sales Behaviour on Customer Satisfaction, Trust and Loyalty to the Company: An Empirical Study in the Financial Services Industry. Journal of Marketing Management, 19 (9-10), 915-939.

Storbacka., Lehtinen., (2005). driving firm performance with strategic account management, Journal of 
Business Ethics, 13 (August), 637647.http://dx.doi.org/10.1007/BF008 71811

Turisman, Teguh., 2014, "Menakar Kinerja Keuangan Multifinance", Majalah Info Bank, No. 425, Vol 36 ,

Wray, B., Palmer, A., \& Bejou, D. (1994). Using neural network analysis to evaluate buyer-seller relationships. European Journal of Marketing, 28(10), 32-48. http://dx.doi.org/10.1108/030905694 10075777

Yi Liu, Yuan Li, Lei Tao and Ying Wang (2008). Relationship stability, trust and relational risk in marketing channels: Evidence from China. Industrial Marketing Management, 37, 432-446. http://dx.doi.org/10.1016/j.indmar man.2007.04.001 
Jurnal Al-Iqtishad, Edisi 11 Volume II Tahun 2015 